\title{
Dynamics of wood in stream networks of the western Cascades Range, Oregon
}

\author{
Nicole M. Czarnomski, David M. Dreher, Kai U. Snyder, Julia A. Jones, and \\ Frederick J. Swanson
}

\begin{abstract}
We develop and test a conceptual model of wood dynamics in stream networks that considers legacies of forest management practices, floods, and debris flows. We combine an observational study of wood in $25 \mathrm{~km}$ of $2 \mathrm{nd}-$ through 5th-order streams in a steep, forested watershed of the western Cascade Range of Oregon with whole-network studies of forest cutting, roads, and geomorphic processes over the preceding 50 years. Statistical and simple mass balance analyses show that natural process and forest management effects on wood input, transport processes, and decomposition account for observed patterns of wood in the stream network. Forest practices reduced wood amounts throughout the network; in headwater streams these effects are fixed in stream segments bordered by cuts and roads, but in larger channels they are diffused along the channel by fluvial transport of wood. Landforms and roads limited delivery of wood by debris flows to mainstem channels. Network dynamics studies and watershed management plans should include spatial patterns of debris flow initiation and runout, flood redistribution, and reduction of wood in the network by forest cutting and intentional wood removal from channels on time scales of forest succession and recurrence of major floods.
\end{abstract}

\begin{abstract}
Résumé : Nous avons développé et testé un modèle conceptuel de la dynamique des bois dans des réseaux de cours d'eau qui tient compte de l'héritage des pratiques d'aménagement forestier, des inondations et du mouvement des débris. Nous combinons une étude basée sur l'observation des bois sur $25 \mathrm{~km}$ de cours d'eau de $2^{\mathrm{e}}$ au $5^{\mathrm{e}}$ ordre dans un bassin versant boisé et aux pentes abruptes situé dans la partie ouest des Cascades, en Oregon, à des études de réseau des coupes forestières, des chemins et des processus géomorphologiques au cours des 50 dernières années. Des analyses statistiques et de bilans simples de masse montrent que les effets des processus naturels et de l'aménagement forestier sur l'apport, les processus de transport et la décomposition des bois expliquent les profils observés de présence des bois dans le réseau de cours d'eau. Les pratiques forestières ont réduit les quantités de bois partout dans le réseau; dans les cours d'eau situés en amont, ces effets sont limités aux segments de cours d'eau bordés par des coupes et des chemins mais, dans les cours d'eau plus larges, ils sont répartis le long du cours d'eau par le transport fluvial des bois. Le relief et les chemins ont limité l'apport de bois en limitant le mouvement des bois vers l'axe fluvial. Les études de dynamique de réseau et les plans d'aménagement de bassin versant devraient inclure le profil spatial du mouvement des débris, de son déclenchement jusqu'à ce qu'il cesse, de la redistribution causée par les inondations, de la diminution des bois dans le réseau à cause de la coupe forestière et de l'enlèvement intentionnel des bois dans les cours d'eau, et cela à l'échelle de temps de la succession forestière et de la récurrence des inondations majeures.
\end{abstract}

[Traduit par la Rédaction]

\section{Introduction}

Since the mid-1970s a very large amount of literature has addressed the abundance, spatial patterns, and functions of wood in streams (Gregory et al. 2003), but a general conceptual model of landscape-scale dynamics of wood in stream networks is still emerging. Conceptual models of wood in streams predict declining wood downstream, as wider channels recruit less wood and can transport larger pieces (Lienkaemper and Swanson 1987; Bilby and Ward 1989; Marcus et al. 2002). Many natural processes and forest management practices - clear-cutting and plantation forestry, roads, floods, geomorphic processes, and other mechanisms - also influence wood dynamics in streams
(Keller and Swanson 1979; Reeves et al. 1995; Johnson et al. 2000; Benda et al. 2002). Wood dynamics in streams have been described using wood budgets and routing analyses (Lancaster and Hayes 2001; Benda et al. 2002; Meleason et al. 2003).

A general conceptual model of wood dynamics in stream networks could integrate these diverse threads and guide forest and watershed managers. Forest regulations increasingly challenge forest managers to predict wood in streams over large landscapes. The Aquatic Conservation Strategy of the Northwest Forest Plan (USDA Forest Service and USDI Bureau of Land Management 1994), for example, requires forest management plans to consider the cumulative upstream effects of harvest and roads as well as past effects of

Received 29 October 2007. Accepted 21 April 2008. Published on the NRC Research Press Web site at cjfr.nrc.ca on 8 July 2008.

N.M. Czarnomski ${ }^{1}$ and J.A. Jones. Department of Geosciences, Oregon State University, Corvallis, OR 97331, USA.

D.M. Dreher and K.U. Snyder. Department of Forest Science, Oregon State University, Corvallis, OR 97331, USA.

F.J. Swanson. USDA Forest Service, Pacific Northwest Research Station, Corvallis, OR 97331, USA.

${ }^{1}$ Corresponding author (e-mail: czarnomn@geo.oregonstate.edu). 
Fig. 1. Conceptual model of wood source and transport processes in a stream network. (a) a stream network (solid thin black lines) consists of a set of locations at which tributaries join higher-order (3rd- to 5th-order) streams, referred to as "mainstem" streams in this paper; (b) wood delivery to streams along channel margins (open arrows) may be reduced by forest harvest (shaded box) and roads (thick broken line); (c) debris flows (black arrows) from tributary streams may convey wood to the mainstem if the debris flow reaches the mainstem; (d) fluvial redistribution of wood may occur at low, intermediate, and high rates, depending on channel width.
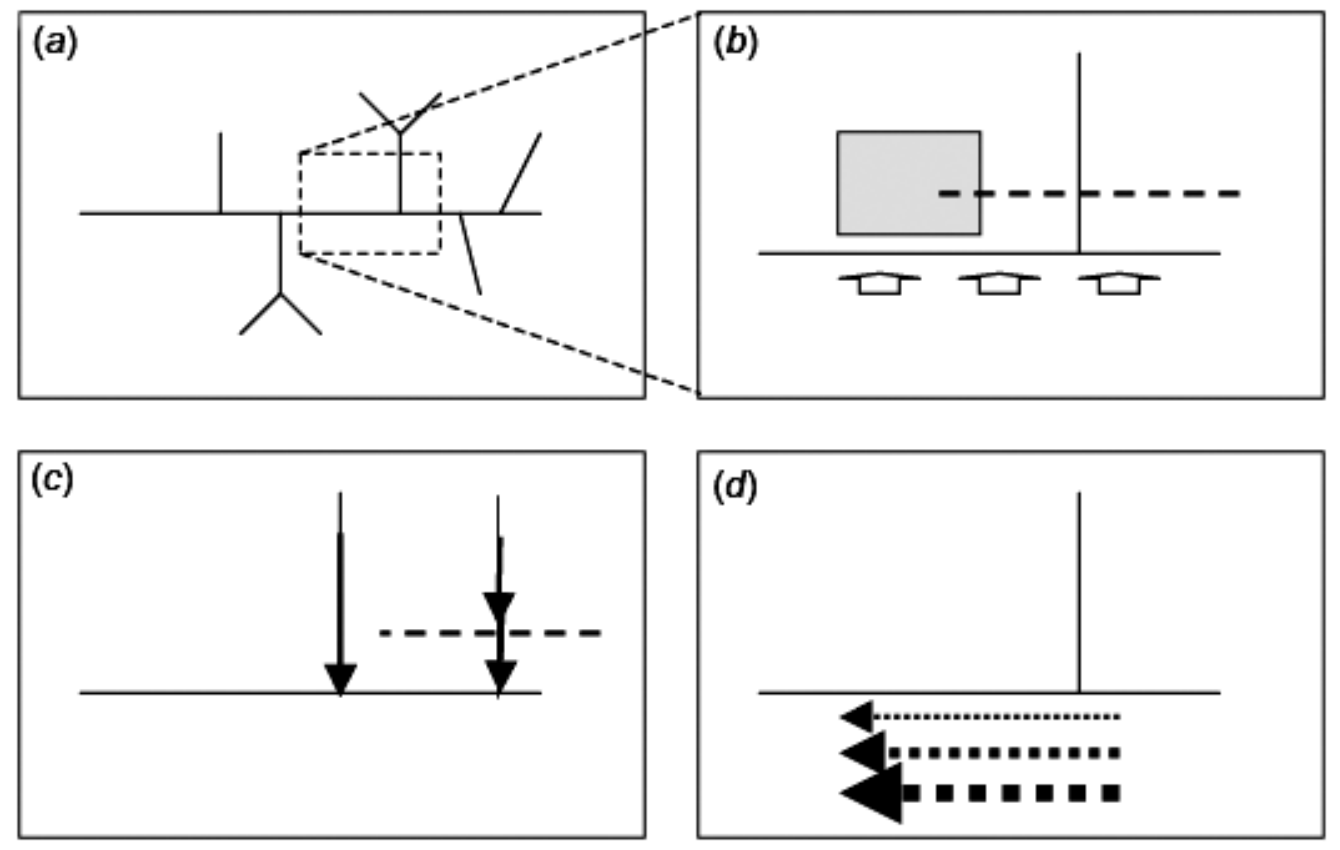

floods and landslides on wood in streams. Equally challenging for forest managers are questions about the effects of road decommissioning or forest management in riparian buffer zones on wood patterns in large stream networks.

Conceptual and technical advances in geospatial analysis, landscape ecology, and long-term ecosystem science provide the basis for a major advance in landscape perspectives on wood in streams. Landscape concepts, including interactions between patchworks and networks, legacies, and network dynamics, are relevant to wood in streams. Forest landscapes consist of patchworks of forest stands of different ages established after disturbance events, including young forests created by past forest cutting (Franklin and Forman 1987; Ripple et al. 1991), networks of roads built to access harvest units (Jones et al. 2000; Forman et al. 2003), and the stream network. Stream network morphology — a population of channels and their confluences - helps predict the spatial distribution of physical diversity in stream networks (Benda et al. 2004a). During natural disturbances such as floods and debris flows, forest patchworks and road and stream networks interact, affecting movement of water, sediment, and wood (Swanson et al. 1998; Wemple et al. 2001). Biological legacies - biotic structures that persist from a predisturbance ecological system - shape ecological and physical processes after natural and human disturbances (Dale et al. 2005). Despite their relevance to wood in streams, no general conceptual model unites these concepts and techniques to describe the dynamics of wood in managed and unmanaged forest stream networks.

Building on concepts in Swanson (2003), we develop a network dynamics conceptual framework to explain patterns of wood in stream networks. The conceptual framework (Fig. 1) considers how different combinations of wood inputs from adjacent forest, debris flows, and fluvial redistribution are arranged in a landscape, producing variations in wood in the stream network (Fig. 1a). The framework includes wood contributions from streamside forests to streams (Fig. 1b) by tree fragmentation, windthrow, bank erosion, and other processes (Keller and Swanson 1979; Lienkaemper and Swanson 1987; McDade et al. 1990; Johnson et al. 2000; Meleason et al. 2003). It also includes effects of forest harvest, roads, and natural processes, such as wildfire and windthrow, on delivery of wood to streams (Benda and Sias 1998; Zelt and Wohl 2004). Clear-cutting removes wood from streamside areas and may have involved salvage logging of downed trees from stream channels. Where mature (80-200 years old) and old-growth (>200 years old) forests are replaced, forest plantations provide much smaller wood pieces to streams. Roads directly replace trees in streamside forests, may involve logging of "hazard trees" in stands adjacent to streams, and provide access for salvage logging from streams.

The conceptual model also includes effects of debris flows on wood in stream networks (Fig. 1c). Debris flows are rapid movements of from hundreds to thousands of cubic metres of sediment, soil, and organic matter, including large wood, down steep, narrow headwater channels (Swanson and Dyrness 1975; Benda et al. 2002; May and Gresswell 2003; Reeves et al. 2003); they are common in steep, forested landscapes of the Pacific Northwest (Sidle et al. 1985; Benda and Cundy 1990; Snyder 2000). Debris flows may move wood from a tributary to a mainstem and redistribute wood within tributaries and the mainstem (May and Gresswell 2004; Bigelow et al. 2007). Clear-cutting, roads, and wildfire influence the initiation and stopping points of debris flows (Swanson and Dyrness 1975; Wemple et al. 2001). 
Fig. 2. Study streams in the upper Blue River drainage watershed, western Cascades, Oregon. Locations of seven study streams (boxes) relative to $(a)$ clearcuts (young forest plantations) and roads, coded by decade and $(b)$ mapped debris flows in 1st order channels of the Lookout Creek watershed and parts of upper Blue River watershed, 1946-present (Dyrness 1967; Swanson and Dyrness 1975; Swanson et al. 1998; Snyder 2000). Cook and Quentin creeks were not included in past debris flow inventories, though evidence of debris flows were recorded during this study.

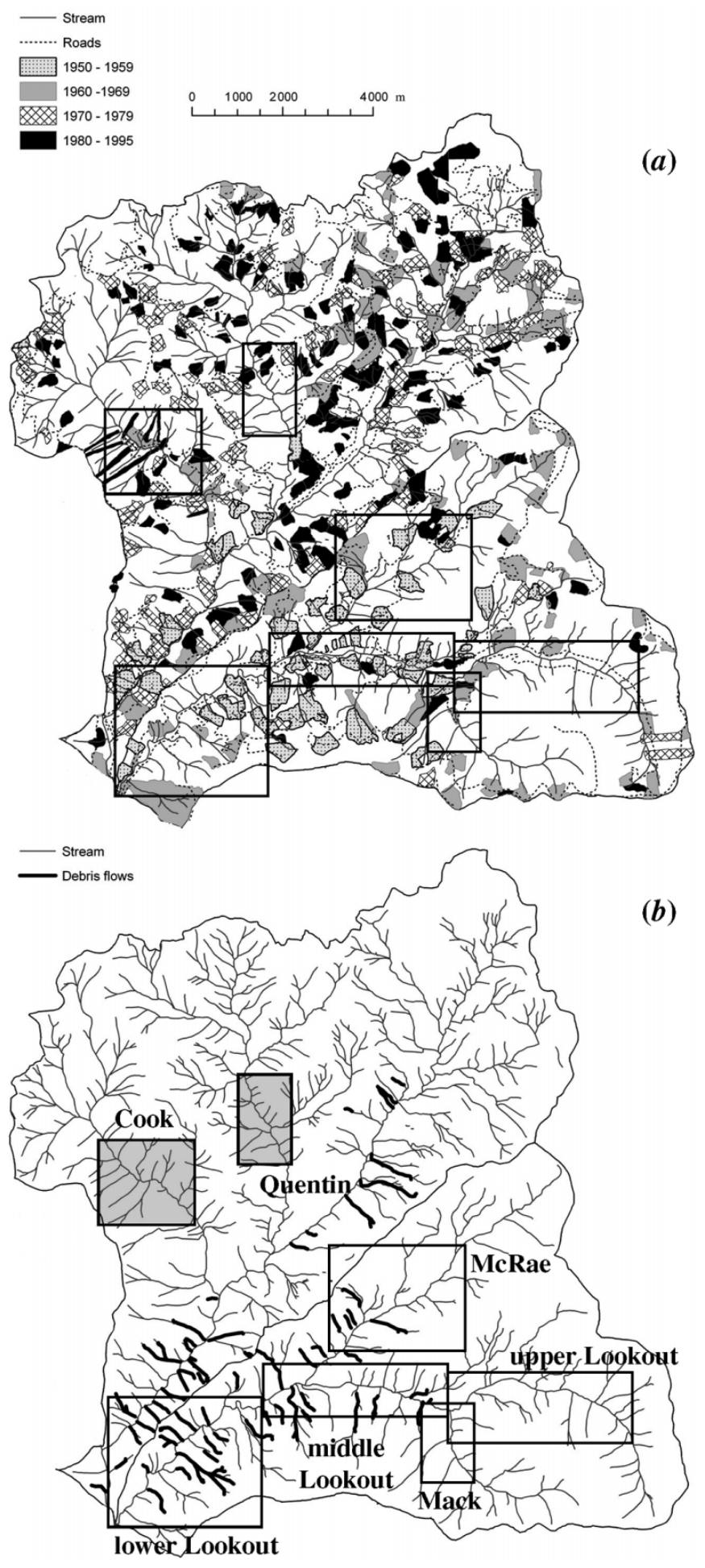

Thus, debris flow wood inputs interact with the pattern of vegetation patches, roads, valley floor morphology, and fluvial redistribution (Fig. $1 b, 1 c$, and $1 d$ ).

The conceptual model also includes fluvial transport of wood (Fig. 1d), which occurs when logs are floated or rolled downstream (Braudrick et al. 1997; Gurnell et al. 2002). The fluvial transport capacity of a stream segment is a function of the ratios of wood piece length to channel width and piece diameter to streamflow depth (Lienkaemper and Swanson 1987; Bilby and Ward 1989; Braudrick et al. 1997). In general, fluvial transport of wood increases downstream. Clear-cutting and roads increase peak flows in steep, forested watersheds (Jones and Grant 1996), with possible indirect effects on wood movement.

This study examines the interacting effects of channel width, geomorphic processes, and the legacy of clearcuts and roads on wood inputs and redistribution in streams from 1948, when forestry practices began, to 2002 in a $200 \mathrm{~km}^{2}$ forested watershed in the western Cascade Range, Oregon. We distill these field observations into a landscapescale conceptual model that considers spatial interactions among road and stream networks, forested patches, and fluvial geomorphic processes to explain spatial and temporal patterns of wood in the stream network and to contribute to the emerging general framework for understanding the dynamics of wood in stream networks.

\section{Methods}

\section{Study area}

The study was conducted in 2002 in seven $1.5-5.0 \mathrm{~km}$ long sections of 3rd- through 5th-order streams (upper, middle, and lower Lookout, Mack, McRae, Quentin, and Cook creeks) in the Blue River watershed in the central Oregon Cascades $\left(44.2^{\circ} \mathrm{N}, 122.2^{\circ} \mathrm{W}\right)$ (Fig. 2, Table 1). The study area consists of deeply dissected mountainous terrain with hillslope gradients ranging from $20 \%$ to $80 \%$, formed from volcanic rock with highly varied susceptibility to erosion (Swanson and James 1975). The climate is maritime; most precipitation falls from November to March, and mean monthly temperature ranges from $2.1{ }^{\circ} \mathrm{C}$ in December to $17.5{ }^{\circ} \mathrm{C}$ in August (Smith 2002). Annual precipitation ranges from $2300 \mathrm{~mm}$ in lower elevations, mainly as rain, to over $3550 \mathrm{~mm}$ at upper elevations, primarily as snow (Swanson and Jones 2002). Forests in the study area are composed primarily of Douglas-fir (Pseudotsuga menziesii (Mirb.) Franco), western hemlock (Tsuga heterophylla (Raf.) Sarg.), and western redcedar (Thuja plicata Donn ex D. Don), with bigleaf maple (Acer macrophyllum Pursh), red alder (Alnus rubra Bong.), and willow (Salix spp.) common in riparian areas. Over $75 \%$ of the area consists of old-growth or mature forest stands regenerated after widespread fire ("unmanaged forests"), with maximum tree heights $>70 \mathrm{~m}$ (Morrison and Swanson 1990). The remaining 25\% of the study area is composed of forest plantations established after clear-cutting (Fig. 2a).

Road construction and forest harvest from 1950 to 1990 created a pattern of dispersed patch clearcuts (20-40 ha) accessible by several hundred kilometres of roads in the study area (Wemple et al. 1996). Most road construction and harvest occurred from 1950 to the early 1970s in Look- 
Table 1. Characteristics of sampled streams in Lookout Creek and Blue River watersheds, Oregon.

\begin{tabular}{lccccc}
\hline $\begin{array}{l}\text { Section } \\
\text { of stream }\end{array}$ & Order & $\begin{array}{l}\text { Sampled } \\
\text { length } \\
(\mathrm{km})\end{array}$ & $\begin{array}{l}\text { Range of } \\
\text { drainage } \\
\text { area (ha) }\end{array}$ & $\begin{array}{l}\text { Channel } \\
\text { width } \\
(\mathrm{m})\end{array}$ & $\begin{array}{l}\text { Channel } \\
\text { gradient } \\
\left({ }^{\circ}\right)\end{array}$ \\
\hline $\begin{array}{l}\text { Lookout } \\
\text { Upper }\end{array}$ & 2 & 1.1 & $405-630$ & $6 \pm 2$ & $8.9 \pm 1.3$ \\
& 3 & 3.9 & $730-1710$ & $12 \pm 3$ & $7.7 \pm 2.1$ \\
Mack & 3 & 1.50 & $490-860$ & $15 \pm 3$ & $6.3 \pm 1.9$ \\
McRae & 3 & 2.05 & $515-830$ & $12 \pm 3$ & $4.1 \pm 1.7$ \\
& 4 & 1.85 & $1130-1445$ & $19 \pm 4$ & $3.1 \pm 0.6$ \\
Middle & 4 & 3.65 & $2575-3425$ & $22 \pm 8$ & $4.5 \pm 1.5$ \\
& 5 & 0.75 & $4985-5275$ & $46 \pm 12$ & $2.5 \pm 0.8$ \\
Lower & 5 & 5.0 & $5275-6240$ & $27 \pm 8$ & $1.7 \pm 0.6$ \\
Blue River & & & & & \\
Cook & 4 & 3.1 & $985-1800$ & $18 \pm 3$ & $2.3 \pm 0.8$ \\
Quentin & 4 & 2.1 & $1625-2215$ & $19 \pm 3$ & $2.0 \pm 1.2$ \\
& & & & & \\
Total & & 25.0 & & & \\
\hline
\end{tabular}

out Creek (including McRae and Mack Creek sample sites) and from 1960 through the 1980s in upper Blue River (Cook and Quentin sites) (Fig. 3; Jones and Grant 1996; Skaugset and Wemple 1999). In-stream salvage logging occurred during the 1960s and early 1970s; this effect can be estimated by proximity of roads and harvests to streams. Two large storm events since 1950 (December 1964-January 1965 and February 1996) initiated extreme floods and debris flows (Fig. 2b) (Swanson et al. 1998; Snyder 2000; Swanson and Jones 2002).

\section{Field methods}

A total of $25 \mathrm{~km}$ of stream length was surveyed in some 2nd-order and all 3rd-, 4th-, and 5th-order channels in Lookout Creek and selected 3rd and 4th-order channels in upper Blue River (Table 1, Fig. 2). All pieces of wood $\geq 10 \mathrm{~cm}$ diameter and $1 \mathrm{~m}$ in length (minimum volume $=0.008 \mathrm{~m}^{3}$ ) in the active channel were located and measured. The active channel was defined as the area in which wood movement was affected by a 50 year flood event, using evidence from the 1996 flood that was still obvious in 2002, such as the condition and arrangement of wood pieces (Swanson et al. 1998). Each piece was classified as "single" (isolated) or as part of an "accumulation" ( $\geq 3$ pieces of in-stream wood with $>2$ points of contact). Each piece was assigned to a $100 \mathrm{~m}$ stream segment based on the location of its centermost point. Wood diameter and length were estimated using a visual classification scheme incorporating three diameter classes $(10-30,30-60$, and $>60 \mathrm{~cm})$, and four length classes $(1-5,5-10,10-20$, and $>20 \mathrm{~m})$. Mean volume for each size and length class combination was calculated using an allometric relationship based on 414 field-measured pieces of wood sampled from several randomly chosen locations in the Lookout Creek watershed (Table 2). Wood volumes of all pieces counted were summed and expressed per $100 \mathrm{~m}$ of stream length. Large pieces were defined as exceeding $1.87 \mathrm{~m}^{3}$ and were $30-60 \mathrm{~cm}$ in diameter and $>10 \mathrm{~m}$ in length or $>60 \mathrm{~cm}$ in diameter and $>5 \mathrm{~m}$ in length (Table 2). The width of the active channel was measured using an Impulse laser surveyor at roughly $25 \mathrm{~m}$ intervals. Locations (starting and ending points) of adjacent natural and human disturbances (e.g., windthrow, bank erosion, harvest units, and roads) were noted (Czarnomski 2003; Dreher 2004).

\section{Classification of stream segments by wood source and transport process}

Each of the stream segments was classified based on the age of adjacent streamside forest and the presence of roads using ArcView version 3.2 geographic information system (GIS) software (Czarnomski 2003). GIS layers of the stream network, watershed boundaries, roads, and forest harvest patches were obtained from Willamette National Forest. The stream layer was dynamically segmented (sensu Longley et al. 2001) into $50 \mathrm{~m}$ intervals and rectified to the field data using major landforms, harvest units, and road and stream intersections as reference points.

A stream segment was defined as "adjacent" to a harvest or road if $\geq 50 \%$ of its length was within $40 \mathrm{~m}$ of the harvest or road. Most wood is contributed by streamside forests from within $40 \mathrm{~m}$ of the stream (Harmon et al. 1986; McDade et al. 1990; Swanson et al. 1990; Meleason et al. 2003), but taller than the $60 \mathrm{~m}$ height commonly achieved by mature and old-growth Douglas-fir can contribute wood from greater distances. The percent length of each $50 \mathrm{~m}$ stream segment adjacent to a harvest unit or road was calculated using GIS software for each of four harvest distances on either side of the stream line: $0 \mathrm{~m}, 1-10 \mathrm{~m}, 10-20 \mathrm{~m}$, and $20-40 \mathrm{~m}$. These values were grouped into $0 \mathrm{~m}, 1-40 \mathrm{~m}$, and $>40 \mathrm{~m}$ for analysis.

Each stream segment in the Lookout Creek watershed also was classified according to its fluvial transport capacity for wood and whether a debris flow had entered that segment from a tributary in the past 50 years (Dreher 2004). Segments affected by slow-moving earthflows were too few to be included in this analysis. Fluvial transport capacity classes were defined based on stream order, measured channel widths, and drainage areas: low (2nd-order, 4$10 \mathrm{~m}, 400-800 \mathrm{ha}$ ), intermediate (3rd-4th-order, 9-40 m, 500-5000 ha), and high (5th-order, 18-62 m, 50006200 ha) fluvial transport capacity. Debris flow pathways were obtained from the H.J. Andrews Forest online spatial database (www.fsl.orst.edu/lter/index.cfm), based on Snyder (2000). A stream segment was classified as affected by debris flow if either $(i)$ it was contained in the mapped debris flow runout pathway from 1996 (two instances, mapped in Wondzell and Swanson 1999 and Johnson et al. 2000) or (ii) a debris flow entered the channel from a tributary within $300 \mathrm{~m}$ upstream of the segment between 1950 and 1995 (six instances, mapped in Swanson et al. 1998 and Snyder 2000) (Fig. 2b).

\section{Statistical analyses}

Wood volume was autocorrelated at up to $100 \mathrm{~m}$ but not beyond $100 \mathrm{~m}$ (Czarnomski 2003), so observations were combined into 250 segments $100 \mathrm{~m}$ long for analysis. Wood volumes, numbers of large pieces, and numbers of accumulations (dependent variables) were related to fluvial transport capacity, debris flow influence, and adjacency to harvest and (or) roads (independent variables) using analysis of variance (ANOVA, PROC MIXED in SAS version 8.2, SAS Institute Inc., Cary, North Carolina). To meet ANOVA assumptions, 
Fig. 3. Intensity of streamside clear-cutting $(a)$ and roads $(b)$ in the study streams. Cumulative proportion of streamside clearcut within $40 \mathrm{~m}$ of the stream, by decade. A value of 0.5 means that $50 \%$ of the length of the stream had a clearcut or road on one or both sides; a value of 1.0 would mean that the entire stream length had a clearcut or road on one or both sides.

(a)

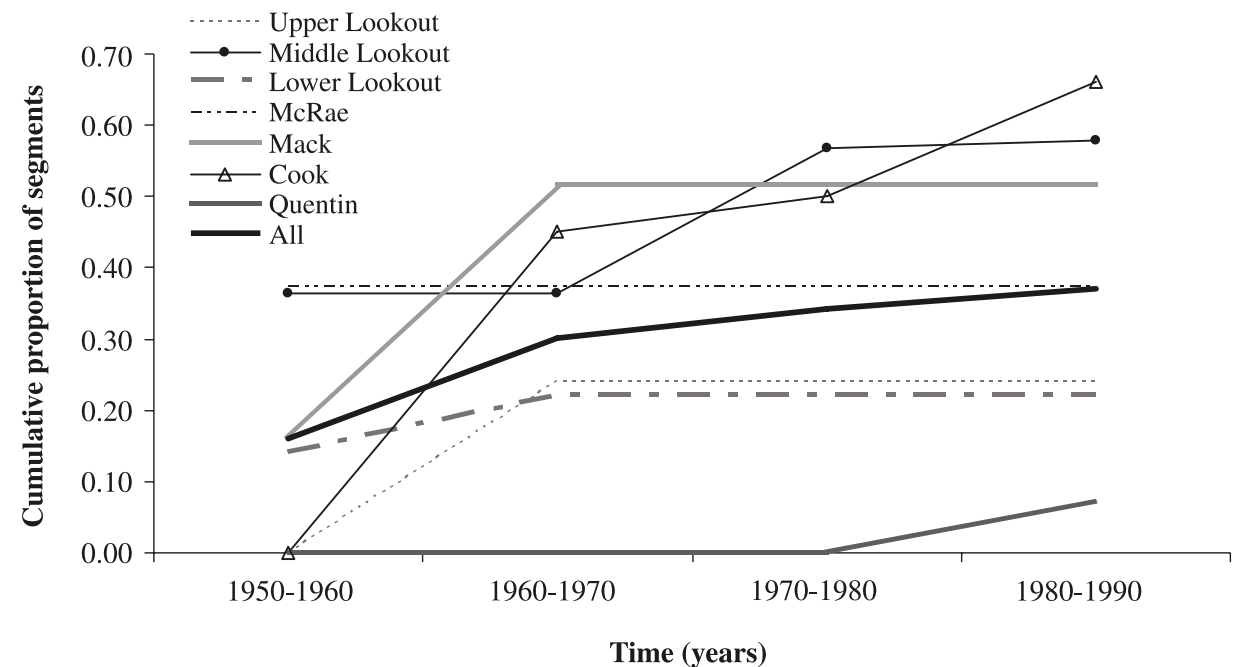

(b)

Time (years)

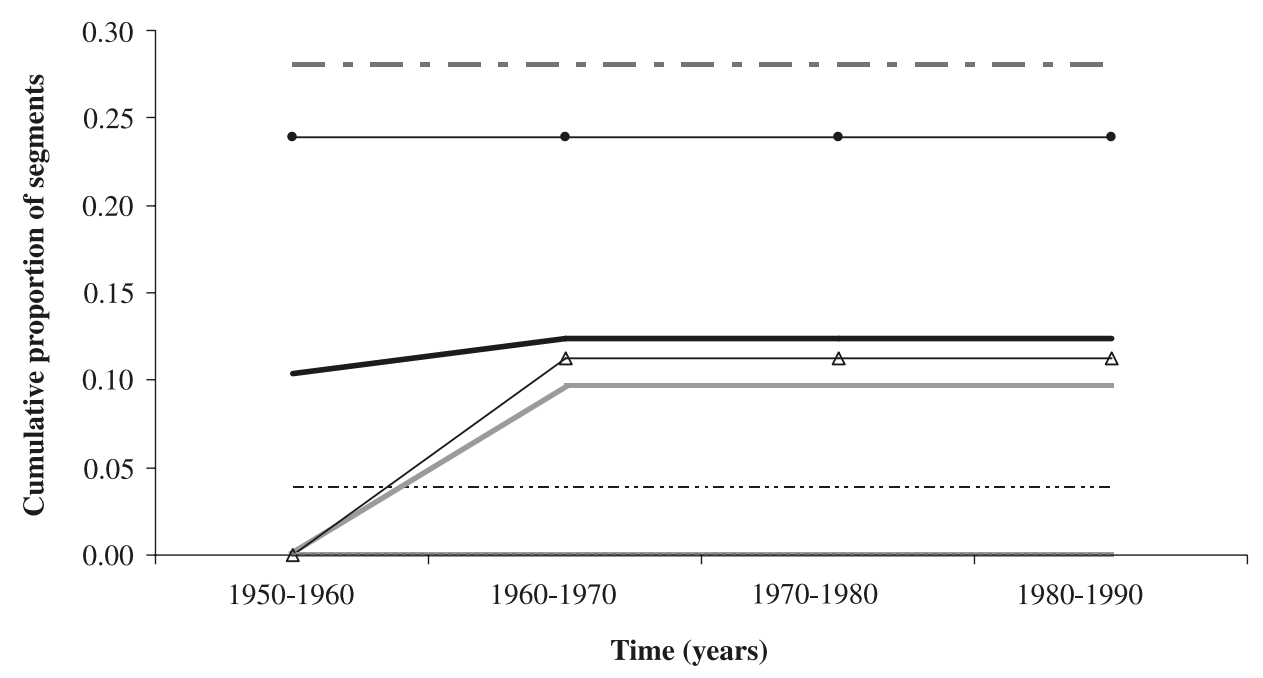

stream segments with zero pieces of large wood were removed from analyses of large pieces. Dependent variables were natural log-transformed for statistical analysis; group means reported in results have been back-transformed. Independent variables were tested for independence prior to ANOVA using $\chi^{2}$ analyses (SAS version 8.2 PROC FREQ). Significant between-group differences were determined using post-hoc pairwise comparisons with $p$ values adjusted using a Bonferroni procedure (Ramsay and Schafer 1997).

\section{Model of wood in streams over time}

The legacies of harvest and flood effects on wood volume in a given stream segment play out over many decades in old-growth forest systems. To explore the temporal dynamics of the four types of wood dynamics in channels (Fig. 1), we simulated wood dynamics over time in streams, contrasting the effects of (i) low versus intermediate and high fluvial transport capacity under mature and old-growth forest with (ii) the effects of converting streamside forest to young forest. The model predicted the wood volume in a stream segment as

$$
V_{t}=V_{t-1} e^{-\mathrm{k}}+I_{t}-O_{t}
$$

where $V_{t}$ is the volume of wood in a stream $\left(\mathrm{m}^{3} / \mathrm{ha}\right)$ in time period $t ; \mathrm{k}$ is the decay constant, including loss from biological decomposition, physical abrasion, and fragmentation of pieces less than the minimum size; $I_{t}$ is the wood input to the stream segment from adjacent forest and upstream in time period $t$; and $O_{t}$ is the number of losses of wood greater than the minimum size for decay from the stream segment to downstream in time period $t$. Input rates in oldgrowth forest were $1.2 \mathrm{~m}^{3} / 100 \mathrm{~m}$, which is consistent with long-term data from Mack Creek (Meleason et al. 2003). Wood depletion by decomposition and fluvial transport of particulate organic matter to the banks or downstream segments was assumed to be $2 \%$ per year, based on measured rates from long-term log decomposition experiments (M.E. Harmon, unpublished data, 9 December 2006) and estimates 
Table 2. Wood volume classes, based on numbers and mean volumes $\left(\mathrm{m}^{3}\right)$ of 414 pieces of wood measured in the field.

\begin{tabular}{|c|c|c|c|c|}
\hline & \multicolumn{4}{|c|}{ Length class } \\
\hline & $1(1-5 \mathrm{~m})$ & $2(5-10 \mathrm{~m})$ & $3(10-30 \mathrm{~m})$ & $4(>20 \mathrm{~m})$ \\
\hline \multicolumn{5}{|c|}{ Diameter class $1(10-30 \mathrm{~cm})$} \\
\hline$N$ & 180 & 43 & 10 & 3 \\
\hline Mean & 0.07 & 0.17 & 0.57 & 0.97 \\
\hline SD & 0.05 & 0.14 & 0.36 & 0.37 \\
\hline \multicolumn{5}{|c|}{ Diameter class $2(31-60 \mathrm{~cm})$} \\
\hline$N$ & 86 & 28 & 9 & 5 \\
\hline Mean & 0.47 & 1.13 & 2.44 & 3.70 \\
\hline SD & 0.26 & 0.51 & 0.89 & 0.97 \\
\hline \multicolumn{5}{|c|}{ Diameter class 3 (>60 cm) } \\
\hline$N$ & 12 & 19 & 10 & 8 \\
\hline Mean & 1.84 & 3.30 & 7.13 & 18.42 \\
\hline SD & 0.95 & 1.05 & 1.92 & 8.57 \\
\hline
\end{tabular}

Note: Volumes were calculated assuming a cylindrical shape, using the mean of the smallest and largest diameters. Values in boldface type are wood piece sizes included in the counts of "large pieces."

of wood residence time (Swanson et al. 1976). In model calculations, net wood export by fluvial processes was assumed to be zero for stream segments with low fluvial transport capacity, but the floods of 1964 and 1996 were assumed to cause a net export of 6-15 years of annual inputs $\left(7-20 \mathrm{~m}^{3}\right.$ / $100 \mathrm{~m}$ ) in streams with intermediate and high fluvial transport capacities, which is consistent with field observations at Lookout Creek (Nakamura and Swanson 1993, 1994; Faustini 2000).

\section{Results}

Overall 20299 pieces of wood with a total volume of $17688 \mathrm{~m}^{3}$ were measured in the $25 \mathrm{~km}$ of sampled streams. Mean values for a $100 \mathrm{~m}$ stream segment were 63 pieces of wood, 7 pieces of large wood, and $49 \mathrm{~m}^{3}$ volume. Single pieces of wood represented only $14 \%$ of pieces (2751 pieces) and $16 \%$ of volume $\left(2850 \mathrm{~m}^{3}\right)$. More than $85 \%$ of pieces were in accumulations anchored by large wood. Large wood represented only $8 \%$ of the number of pieces (1468 pieces), but represented $66 \%$ of wood volume $\left(9818 \mathrm{~m}^{3}\right)$. Most $100 \mathrm{~m}$ segments had between 10 and $150 \mathrm{~m}^{3}$ volumes and between 20 and 150 pieces of wood. Less than $2 \%$ of surveyed stream lengths had fewer than 10 pieces of wood per $100 \mathrm{~m}$, and almost $6 \%$ of surveyed stream lengths had more than $150 \mathrm{~m}^{3}$ of wood per $100 \mathrm{~m}$. The maximum number recorded was 465 pieces of wood with a volume of $550 \mathrm{~m}^{3}$ per $100 \mathrm{~m}$ segment, in Lookout Creek. Harvests and roads were evenly distributed throughout the stream network (Fig. 2a). Most harvests in the 1950s and 1960s had no riparian buffer, but after 1970 about half of the harvests had buffers of $40 \mathrm{~m}$ (Fig. 3).

Virtually all debris flows that might have delivered wood intersected 4th- and 5th-order streams with high fluvial transport capacities (Fig. 2b). Tributary junctions and stream segments intersected by debris flows in Lookout Creek were disproportionately concentrated at low elevation. Debris flows intersected half to four-fifths of junctions linking 1stor 2 nd-order tributaries to 4 th- or 5 th-order streams, and all 4th- and 5th-order stream segments experienced tertiary debris flow runout (Table 3). Many debris flows stalled in 1st-order channels without reaching a tributary junction. Only a few debris flows emerged from 1st-order channels into other 1st- or 2nd-order channels, and all of these continued into a 4 th- or 5th-order channel (Fig. 2b, Table 3). No debris flows intersected tributary junctions linking 1st-, 2nd-, or 3rd-order tributaries to 3rd-order streams. Stream segments affected by debris flow were evenly divided between harvest and (or) road effects and no harvest and (or) road effects (Table 4).

The stream network in this study displayed four different combinations of wood source and transport processes at tributary junctions (Table 4, Figs. 2 and 4): (i) no debris flows in the past 50 years and low to intermediate fluvial redistribution of wood; (ii) debris flows that reached the mainstem and intermediate fluvial redistribution of wood; (iii) roads, debris flows that did not reach the mainstem, and intermediate fluvial redistribution of wood; and (iv) roads, debris flows that reached the mainstem, and high fluvial redistribution of wood.

Overall, wood volumes decreased in the downstream direction, and controlling for position in the stream network, segments adjacent to young forest plantations or roads had significantly less wood than those adjacent to mature or old-growth forest without roads (Fig. 5a). When only segments adjacent to mature or old-growth forest were considered, wood volumes and numbers of large pieces decreased, but not significantly, with increasing fluvial transport capacity (Table 5). Controlling for fluvial transport capacity, stream segments intersected by a debris flow runout path had equivalent or significantly less wood than segments not in debris flow runout paths (Table 5).

Harvests and roads explained much of the variability of wood in streams (Table 6). Wood volumes and numbers of large pieces were significantly higher in stream segments adjacent to unmanaged, mature, and old-growth forest compared with segments adjacent to 30- to 50-year-old forest plantations (former harvests) and (or) roads. Stream segments with young forest plantations on both sides had significantly less wood than any other type of stream segment. All but one stream segment lacking wood altogether were adjacent to harvests and (or) roads. Stream segments adjacent to 30- to 50-year-old plantations (harvests in the 1950s and 1960s) had significantly less wood volume and fewer large pieces than stream segments adjacent to 20- to 30-year-old plantations (harvests in the 1970s and 1980s) or mature and old-growth forest. Stream segments with riparian buffers $<40 \mathrm{~m}$ had significantly less wood volume and fewer large pieces than those with riparian buffers $>40 \mathrm{~m}$.

Wood volume and numbers of large pieces were significantly lower in stream segments adjacent to mature or oldgrowth forest if they were located within $100 \mathrm{~m}$ upstream or downstream of young forest plantations and roads, relative to stream segments adjacent to mature or old-growth forest and more than $100 \mathrm{~m}$ from the nearest road or young forest patch (Table 7). This effect was especially pronounced in streams with high fluvial transport capacity: stream segments with high fluvial transport capacity adjacent to mature or old-growth forest but $100 \mathrm{~m}$ downstream 
Table 3. Network structure effect on dynamics of wood movement via debris flows in Lookout Creek, Oregon, from 1946 to the present (see Fig. 2b): percentage of tributary junction types affected by debris flow transportation tracks and percentage of stream network length affected by primary, secondary, and tertiary effects of debris flows.

\begin{tabular}{|c|c|c|c|c|c|c|c|c|}
\hline \multirow[b]{2}{*}{$\begin{array}{l}\text { Order of } \\
\text { receiving stream }\end{array}$} & \multicolumn{5}{|c|}{ Order of contributing stream } & \multicolumn{3}{|c|}{ Percentage of stream length } \\
\hline & 1 & 2 & 3 & 4 & All* & Network & Primary effects ${ }^{\dagger}$ & $\begin{array}{l}\text { Secondary and } \\
\text { tertiary effects }{ }^{\dagger}\end{array}$ \\
\hline 1 & 14 & & & & 14 & 59 & 12 & 2 \\
\hline 2 & 11 & 10 & & & 20 & 23 & 23 & 7 \\
\hline 3 & 0 & 0 & 0 & & 0 & 7 & 34 & 13 \\
\hline 4 & 50 & 80 & 0 & & 52 & 6 & 0 & 67 \\
\hline 5 & 65 & 63 & 100 & 0 & 65 & 5 & 0 & 100 \\
\hline All* & 25 & 29 & 20 & 0 & 25 & 100 & 15 & 10 \\
\hline
\end{tabular}

\footnotetext{
Note: Numbers for stream lengths affected by debris flows are from Snyder (2000).

*The total number of contributing (receiving) streams with debris flows as a percentage of the total number of contributing (receiving) streams in the network.

The primary disturbance zone refers to the debris flow runout track. The secondary disturbance zone extends from the termination of a debris flow transportation track to the mainstem and includes riparian vegetation disturbance and sediment deposition by fluvial processes distinct from the debris flow. The tertiary disturbance zone refers to disturbance of riparian vegetation and the stream channel accentuated by the contribution of sediment and wood delivered by the debris flow (Snyder 2000).
}

of young forest or roads had much lower wood volumes than segments $100 \mathrm{~m}$ upstream of young forests or than comparable stream segments with intermediate fluvial transport capacity (Fig. $5 b$ ).

According to simulations over time, harvest in the $1950 \mathrm{~s}$ of old-growth forest adjacent to streams combined with wood removal observed in the study landscape during the floods of 1964 and 1996 explain the wood volumes measured in 2002 (Fig. 6). Relative to wood regimes in unmanaged forests, simulated wood volumes declined by two-thirds from 1950 to 2005 in streams that had experienced $(i)$ clear-cutting and plantation establishment on both sides of the stream in 1955 or (ii) clear-cutting and plantation establishment on one side of the stream in 1955 plus high net fluvial transport of wood from the stream segment in floods of 1964 and 1996 (Fig. 6). Simulations reproduced wood volumes measured in 2002 (Fig. 6).

\section{Discussion}

Several features of the forest management and flood histories of the study site influenced the landscape-scale patterns of wood in streams: $(i)$ a high contrast in input rates of large wood from mature and (or) old-growth versus young forest; (ii) the limited use of riparian buffers along streams; and (iii) distributed patch clear-cutting of oldgrowth occurred from 1948 to the early 1970s and then largely ceased, providing a landscape mosaic of patches of young forest plantations in a matrix of mature and oldgrowth forest (Fig. 2). Long-term, landscape-scale records of dates, locations, and magnitudes of harvests, roads, debris flows, floods, and various combinations of these factors (Table 4) made it is possible to disentangle their effects on wood in streams. Fluvial processes had three to five decades and at least two extreme floods to assert their influences on wood patterns and dynamics. Because a 50 year flood occurred 6 years before our sampling effort, the imprint of fluvial redistribution was strong, rather than overprinted by decades of wood input from streamside forests (Swanson 2003). Despite these particular circumstances, the study pro- vides support for a general conceptual model of wood in stream networks.

\section{Distribution and abundance of wood at the watershed scale and wood dynamics in the stream network}

A general conceptual model of wood dynamics must consider combinations of fluvial transport, harvests and roads, and debris flow processes at tributary junctions (Fig. 4). Stream order was not sufficient to predict volumes and numbers of large pieces of wood in stream networks because harvests and roads reduce wood and debris flows and fluvial transport rearrange wood. Accurate prediction of wood in stream networks requires a network dynamics approach (Benda et al. 2004b) that considers populations of tributary junctions, properties of tributary watersheds, and their effects on wood dynamics.

This study did not find large decreases in wood downstream in wider channels with higher fluvial transport capacities as predicted or observed in many studies (Marcus et al. 2002; May and Gresswell 2003; Swanson 2003). This result may be because some 5th-order channels in the study that were classified as having high fluvial transport capacity are only $25-30 \mathrm{~m}$ wide, about the length of some large pieces, and some channels classified as intermediate were quite wide (Tables 1 and 2). Another explanation for the lack of a significant decline in wood with increasing fluvial transport capacity is that fluvial export of wood from intermediate and high fluvial transport capacity segments was balanced by debris flows, which delivered wood primarily to stream segments with intermediate and high fluvial transport capacities (Fig. 2b, Table 3).

Consistent with many studies, this study confirmed that harvest and roads adjacent to streams were associated with significant and persistent reductions of wood in streams where $<40 \mathrm{~m}$ buffer strips were used. Causes of decreased wood in streams associated with roads and harvest include intentional removal of wood from streams, replacement of mature and old-growth streamside forests with roads or young forest, and altered wood transport in the stream net- 
Table 4. Number of $100 \mathrm{~m}$ stream segments sampled for wood by stream order, fluvial transport capacity class, harvest and (or) road effect, and debris flow effect in upper Blue River, Oregon.

\begin{tabular}{lrllllr}
\hline $\begin{array}{l}\text { Fluvial transport } \\
\text { capacity class }\end{array}$ & $\begin{array}{l}\text { Stream } \\
\text { order }\end{array}$ & None & $\begin{array}{l}\text { Harvest and } \\
\text { (or) roads }\end{array}$ & $\begin{array}{l}\text { Debris } \\
\text { flow }\end{array}$ & $\begin{array}{l}\text { Harvest and (or) } \\
\text { roads and debris flow }\end{array}$ & Total \\
\hline $\begin{array}{l}\text { Lookout Creek } \\
\text { Low }\end{array}$ & 2 & 12 & - & - & - & 12 \\
$\quad \begin{array}{l}\text { Intermediate } \\
\text { High }\end{array}$ & $3-4$ & 59 & 39 & 8 & 6 & 112 \\
$\quad$ Earthflow-affected & 5 & 29 & 7 & 11 & 10 & 57 \\
Blue River & 4 & - & - & - & - & 17 \\
Total & & & & & & 52 \\
\hline
\end{tabular}

work. Removal of in-stream wood by salvage logging and removal of wood sources by streamside forest by selection cutting and clear-cutting can substantially decrease the standing crop of wood in streams, despite long residence times for large pieces of wood, which may substantially exceed 50-100 years (Swanson et al. 1976; Lienkaemper and Swanson 1987; Hyatt and Naiman 2001; Gurnell et al. 2002). Young forests have smaller trees, which decay faster and are less geomorphically and ecologically effective than large wood contributed by mature and old-growth forest (Keim et al. 2000; Zelt and Wohl 2004; Gomi et al. 2006). Forest road networks - typically branching hierarchical networks with a trunk road and branches to access harvest units (Silen 1955; Forman et al. 2003) — often run adjacent to mainstem streams where they permanently replace forest and reduce wood loading along the mainstem and cross tributary streams where they may block wood delivery from tributaries (Wemple et al. 2001).

Unlike previous studies of wood in stream networks, this study showed that patchwork-network interactions among young forest plantations (patchwork), the road network, and the stream network explain spatial patterns of wood in this site. In stream reaches where large wood pieces are rarely or never transported by streamflow, reduced wood inputs from young forest or roads produce a persistent but localized effect, with abrupt transitions in wood volume and density of large pieces between stream reaches adjacent to roads or young forest versus those adjacent to mature or old-growth forest (Fig. 4a). In wider channels, where flood and debris flow-related processes rearrange wood (Johnson et al. 2000; Marcus et al. 2002), reduced wood inputs from young forest or roaded areas may extend hundreds of metres downstream (Fig. 4d). Along wider channels wood is depleted as a cumulative result of upstream reductions in wood inputs due to numerous cut patches and roads; periodic transport events rearrange these reduced amounts of wood, blurring the transitions in wood amounts between stream segments adjacent to young forest versus those adjacent to mature or old-growth forest (Fig. $5 b$ ).

This study also revealed that the spatial pattern of debris flow contributions of wood in the stream network interacts with fluvial transport capacity and harvest and (or) road effects. Debris flows were less important mechanisms for delivering wood from 1st- and 2nd-order streams to mainstem channels in the study site than is reported in some other studies in different geological and physiographic contexts. For example, debris flows may substantially augment wood in mainstem channels in landscapes, such as the Ore- gon Coast Range, where debris flows deliver wood from numerous tributaries to mainstems with low to intermediate fluvial transport capacity, potentially comprising a major source of wood in some mainstem channels (Benda et al. 2002; Marcus et al. 2002; May and Gresswell 2003, 2004; Reeves et al. 2003; Bigelow et al. 2007). In contrast, in the study landscape in the Oregon Cascade Range, debris flows had a minor observed effect on wood in mainstem channels for two reasons: $(i)$ geologic factors severely limit occurrence of debris flows in some tributary watersheds (Swanson and Dyrness 1975) and (ii) debris flows rarely reached mainstem channels (Table 3).

Debris flows from steep tributary streams have three potential interactions with the mainstem stream. They may (i) deposit on the valley floor without reaching the mainstem channel (e.g., on an alluvial fan, floodplain, or above a road fill) (Grant and Swanson 1995; Wemple et al. 2001; May and Gresswell 2004), (ii) reach the mainstem channel where wood piles up, forming a distinct deposit (Reeves et al. 2003; Benda et al. 2004a; Bigelow et al. 2007), or (iii) reach a mainstem channel with the capacity to fluvially redistribute the wood, so a pile of wood does not persist at the stream junction (Swanson et al. 1998; Johnson et al. 2000). Given an inventory of debris flows, the proportions of debris flows that displayed each of these distinctive behaviors can be counted (e.g., Nakamura et al. 2000). In the study landscape, many dozens of debris flows rearranged wood in tributary streams of the study area in the 1964 and 1996 floods; however, all but eight of these failed to reach the mainstem because they stopped on a wide valley floor or were blocked by a road crossing the stream, and the wood was removed during road repair (Swanson et al. 1998; Snyder 2000; Wemple et al. 2001). The eight debris flows that delivered wood to the mainstem did not leave discrete piles of wood in the mainstem channel because wood was delivered to a channel with high fluvial transport capacity during a major flood, and the wood was transported downstream out of the study area or deposited in the channel or on floodplains. Piles of wood deposited by debris flows at the confluence of streams, a conspicuous feature of some stream networks, are absent in our study area because tributaries intersecting mainstem channels where such piles would persist are not subject to debris flows because of topographic and soils constraints (Swanson and Dyrness 1975; Snyder 2000).

\section{Temporal dynamics of wood}

Simulations of wood dynamics for the 1945-2005 period in stream segments under four sets of conditions of adjacent 
Fig. 4. The stream network in this study was characterized by four different combinations of wood source and transport processes: (a) 2nd- to 3rd-order streams with young, mature, and old-growth forest adjacent to the stream, no debris flows in the past 50 years, and low to intermediate fluvial redistribution of wood in the channel (upper Lookout and Mack); (b) 3rd- to 4th-order streams with young, mature, and old-growth forest adjacent to the stream, some debris flows that reached the mainstem, and intermediate fluvial redistribution of wood in the channel (McRae, Cook, and Quentin); (c) 4th and 5th order streams with young, mature, and old-growth forest and roads adjacent to the stream, debris flows did not reach the mainstem, and intermediate fluvial redistribution of wood in the channel (middle Lookout); and (d) 5th order streams with young, mature, and old-growth forest and roads adjacent to the stream, debris flows that reached the mainstem, and high fluvial redistribution of wood in the channel (lower Lookout) (see Table 4).

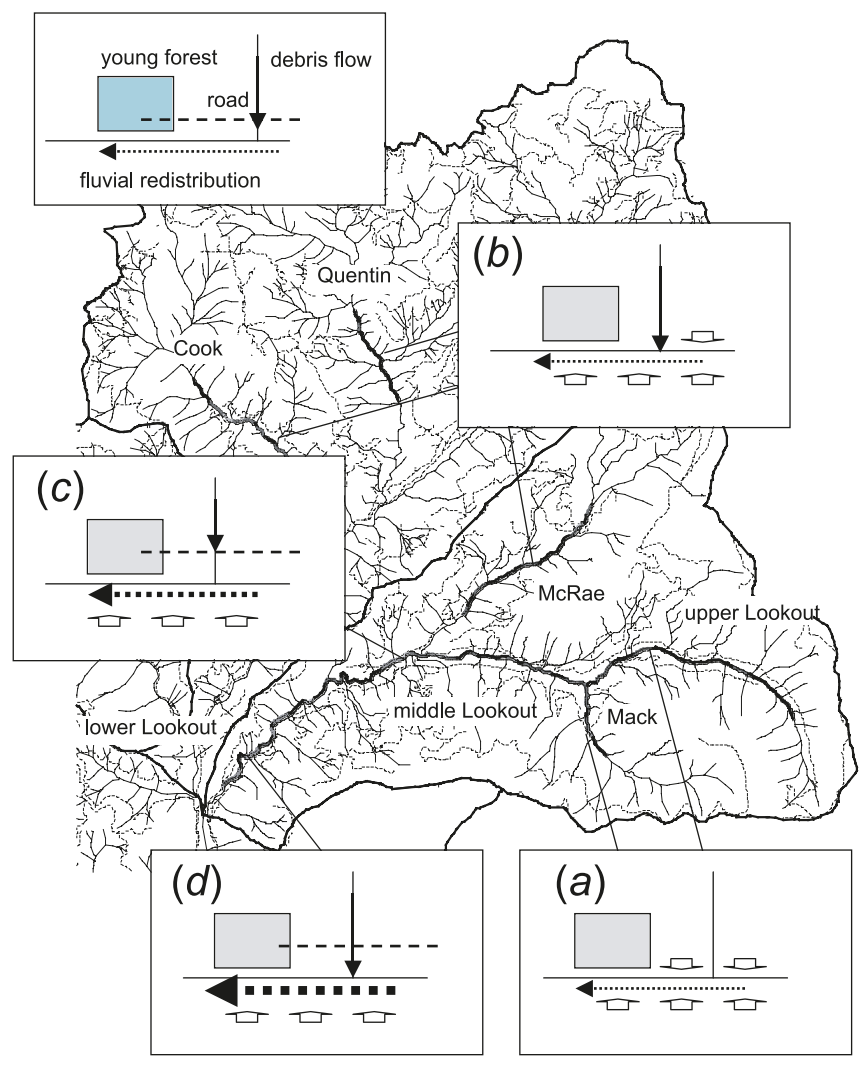

forest age and fluvial transport capacity accurately reproduced the wood volumes measured in 2002. Simulations indicate that over the 60 year period, 50\%-66\% reductions in wood volume occurred in stream segments with harvest on one side and low fluvial transport capacity as well as in those with harvest on one side and high fluvial transport capacity. Simulations show that without harvest, stream segments with low fluvial transport capacity maintained steady wood volumes, and stream segments with intermediate fluvial transport capacity maintained temporally fluctuating but non-declining wood volumes, consistent with field observations (Nakamura et al. 2000). Simulations suggest that in streams with high fluvial transport capacity, additions of wood contributed by debris flows are overwhelmed by fluvial rearrangement and net export, resulting in steady or reduced wood volumes in stream segments at the end of debris flow runout paths.
Fig. 5. Interaction of fluvial transport with harvest, roads, debris flow runout, and neighborhood effects on wood volume (m3/100 m) in streams of upper Blue River, Oregon. (a) Interaction of low, intermediate, and high fluvial transport capacity classes with harvest and (or) road effects and effects of debris flow runout paths. (b) Interaction of intermediate and high fluvial transport capacity classes with neighborhood effects.
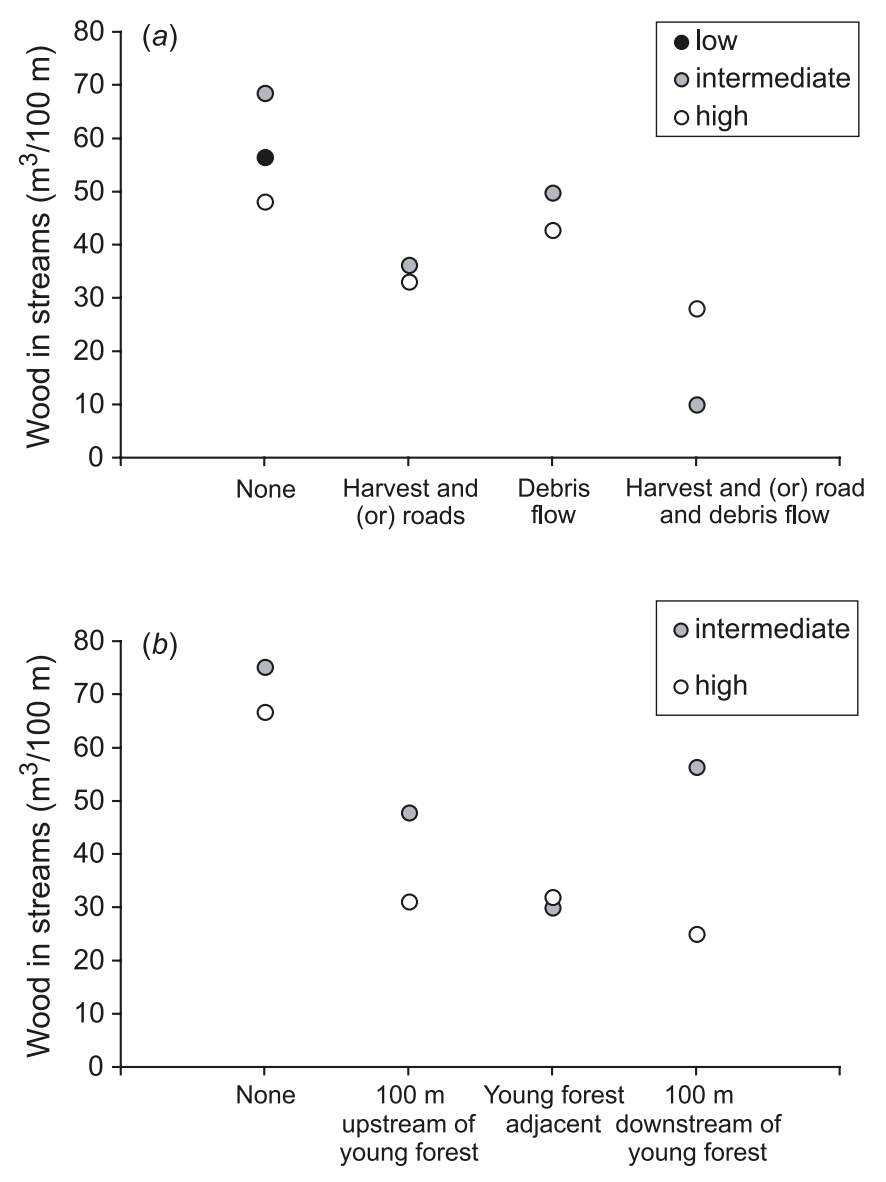

\section{Implications for forest management}

Legacies of past forest management practices persist in both streamside vegetation and in-stream wood, even though forestry practices have changed greatly in the Pacific Northwest region where this study took place. Current forestry practices are no longer creating the same legacies on public lands in the Pacific Northwest. Wider riparian buffers have been adopted since the 1960 s, and road construction practices have been modified to reduce impacts to streams. Since the early 1990s, clear-cutting of old-growth forest has nearly ceased on public forest lands, extensive (approximately $50 \mathrm{~m}$ wide) riparian reserves (buffer strips) are employed along streams, and plantations are thinned to foster oldgrowth stand characteristics in some areas.

A network dynamics model of wood in streams can guide landscape plans for forest management (Fig. 4). The model focuses attention on the long-term function of streamside forests as wood sources, relative to the ability of their adjacent channel to retain or transport wood. The role of a forest patch of a given age in wood dynamics depends on its location in the stream network, the upstream distribution of forest patches and roads, and the likely rearrangement of the 
Table 5. Effect of fluvial transport capacity and interactions of fluvial transport with debris flow runout paths on wood in streams in Lookout Creek, Oregon.

\begin{tabular}{|c|c|c|c|c|c|c|c|}
\hline Fluvial transport capacity class & $N$ & $\begin{array}{l}\text { Volume } \\
\left(\mathrm{m}^{3} / 100 \mathrm{~m}\right)\end{array}$ & $95 \% \mathrm{CI}$ & $N$ & $\begin{array}{l}\text { No. of large } \\
\text { pieces per } 100 \mathrm{~m}\end{array}$ & $95 \% \mathrm{CI}$ & $\begin{array}{l}\text { No. of segments with } \\
\text { zero large pieces }\end{array}$ \\
\hline \multicolumn{8}{|l|}{ Fluvial transport capacity } \\
\hline Low - fluvial & 12 & $56.5 \mathrm{a}$ & $26.1,122.6$ & 11 & $10 \mathrm{a}$ & 4,21 & 1 \\
\hline Intermediate - fluvial & 98 & $53.2 \mathrm{a}$ & $40.6,69.8$ & 96 & $7 \mathrm{a}$ & 6,10 & 2 \\
\hline High - fluvial & 35 & $41.0 \mathrm{a}$ & $26.1,64.6$ & 33 & $6 a$ & 4,9 & 2 \\
\hline \multicolumn{8}{|c|}{ Debris flow runout and intermediate fluvial transport capacity } \\
\hline Intermediate - fluvial & 98 & $53.2 \mathrm{a}$ & $11.9,53.0$ & 96 & $7 \mathrm{a}$ & 3,13 & 2 \\
\hline Intermediate - debris flow & 14 & $25.1 b$ & $40.1,70.6$ & 11 & $6 \mathrm{a}$ & 6,10 & 3 \\
\hline \multicolumn{8}{|c|}{ Debris flow runout and high fluvial transport capacity } \\
\hline High - fluvial & 35 & $41.0 \mathrm{a}$ & $17.7,68.1$ & 33 & $6 \mathrm{a}$ & 3,10 & 2 \\
\hline High - debris flow & 22 & $34.7 \mathrm{a}$ & $24.1,69.9$ & 21 & $5 a$ & 4,10 & 1 \\
\hline
\end{tabular}

Note: Seventeen segments with earthflow influence were removed from analysis, as well as segments with zero large pieces. The remaining segments were divided into the fluvial transport capacity classes before analysis. Mean values followed by the same letter are not significantly different at a Boneferroni-adjusted $p<0.05$.

Table 6. Effect of adjacent harvest and road treatment, decade of harvest, and riparian buffer width on wood in streams in the upper Blue River watershed, Oregon.

\begin{tabular}{|c|c|c|c|c|c|c|c|}
\hline & $N$ & $\begin{array}{l}\text { Volume } \\
\left(\mathrm{m}^{3} / 100 \mathrm{~m}\right)\end{array}$ & $95 \% \mathrm{CI}$ & $N$ & $\begin{array}{l}\text { No. of large } \\
\text { pieces per } 100 \mathrm{~m}\end{array}$ & $95 \% \mathrm{CI}$ & $\begin{array}{l}\text { No. of segments } \\
\text { with zero large } \\
\text { pieces }\end{array}$ \\
\hline \multicolumn{8}{|c|}{ Harvest and road treatment } \\
\hline None & 155 & $65.2 \mathrm{a}$ & $57.7,80.6$ & 154 & $9 \mathrm{a}$ & 8,11 & 1 \\
\hline Harvest, one side & 50 & $36.6 \mathrm{~b}$ & $25.2,53.2$ & 46 & $6 b$ & 4,8 & 4 \\
\hline Harvest, two sides & 15 & $20.8 \mathrm{c}$ & $10.5,41.2$ & 12 & $3 c$ & 2,7 & 3 \\
\hline Roads & 12 & $29.5 \mathrm{bc}$ & $13.8,63.3$ & 11 & $5 b c$ & 3,11 & 1 \\
\hline Harvestand roads & 18 & $28.2 \mathrm{bc}$ & $15.1,52.6$ & 17 & $4 c$ & 2,6 & 1 \\
\hline \multicolumn{8}{|l|}{ Decade of harvest } \\
\hline No harvest & 156 & $64.1 \mathrm{a}$ & $51.0,78.9$ & 154 & $9 \mathrm{a}$ & 8,11 & 2 \\
\hline Harvest in 1950s & 35 & $32.9 b$ & $21.2,51.0$ & 31 & $5 b$ & 3,8 & 4 \\
\hline Harvest in $1960 \mathrm{~s}$ & 34 & $23.5 b$ & $15.0,36.6$ & 31 & $3 \mathrm{c}$ & 2,5 & 3 \\
\hline Harvest in 1970s-1980s & 13 & $67.0 \mathrm{a}$ & $32.6,137.6$ & 13 & $9 \mathrm{a}$ & 5,17 & 0 \\
\hline \multicolumn{8}{|l|}{ Buffer width } \\
\hline $0 \mathrm{~m}$ from stream & 55 & $28.3 \mathrm{a}$ & $19.8,40.5$ & 51 & $4 a$ & 3,6 & 4 \\
\hline $1-40 \mathrm{~m}$ from stream & 27 & $40.9 \mathrm{a}$ & $24.6,68.1$ & 24 & $7 \mathrm{~b}$ & 4,11 & 3 \\
\hline$>40 \mathrm{~m}$ from stream & 156 & $64.1 b$ & $51.8,79.2$ & 154 & $9 \mathrm{c}$ & 8,11 & 2 \\
\hline
\end{tabular}

Note: Mean values followed by the same letter are not significantly different at a Bonferroni-adjusted $p<0.05$.

Table 7. Effect of neighboring upstream and downstream young forest plantations and roads on wood in streams in the upper Blue River watershed, Oregon.

\begin{tabular}{|c|c|c|c|c|c|c|c|}
\hline Neighborhood class & $N$ & $\begin{array}{l}\text { Volume } \\
\left(\mathrm{m}^{3} / 100 \mathrm{~m}\right)\end{array}$ & $95 \% \mathrm{CI}$ & $N$ & $\begin{array}{l}\text { No. of large } \\
\text { pieces per } \\
100 \mathrm{~m}\end{array}$ & $95 \% \mathrm{CI}$ & $\begin{array}{l}\text { No. of } \\
\text { segments } \\
\text { with zero } \\
\text { pieces }\end{array}$ \\
\hline No young forest and (or) roads within $100 \mathrm{~m}$ & 107 & $77.4 \mathrm{a}$ & $60.2,99.5$ & 106 & $11 \mathrm{a}$ & 9,14 & 1 \\
\hline $0-100 \mathrm{~m}$ upstream of young forest and (or) roads & 25 & $44.3 b$ & $26.4,74.4$ & 25 & $6 b$ & 4,10 & 0 \\
\hline Young forest and (or) roads adjacent & 95 & $31.0 \mathrm{~b}$ & $23.8,40.5$ & 86 & $5 b$ & 4,6 & 9 \\
\hline $0-100 \mathrm{~m}$ downstream of young forest and (or) roads & 23 & $44.6 b$ & $26.0,76.6$ & 23 & $4 \mathrm{~b}$ & 4,10 & 0 \\
\hline
\end{tabular}

Note: Mean values followed by the same letter are not significantly different at a Bonferroni-adjusted $p<0.05$.

wood it contributes to the adjacent channel, given the fluvial transport capacity of that channel. This approach fosters consideration of forestry practices according to their ability to contribute wood both to adjacent channels and downstream. For example, practices such as thinning of young stands may accelerate growth of large trees that may be future sources of wood for streams in areas where wood has been depleted by removal of old-growth forests. Culvert replacement by rolling dips on roads crossing streams may facilitate wood delivery to streams by debris flows from 
Fig. 6. Temporal dynamics of wood in steep, forested streams under four combinations of harvest and (or) roads and fluvial transport capacity. Simulated clear-cutting and plantation establishment occurred in 1955 on one or both sides of the stream and simulated fluvial transport removed wood episodically at low, intermediate, or high rates in the floods of 1964 and 1996 (see text). Simulations were: (i) 20- to 50-year-old forest on both sides of the stream (thick black broken line and squares), (ii) mature and (or) old-growth forest or 50-year-old forest on one side of the stream and high removal of wood by floods in 1964 and 1996 (grey broken line, shaded and open circles), and (iii) mature or old-growth forest with low fluvial transport capacity of wood (thin black and thick grey solid lines and solid circles).

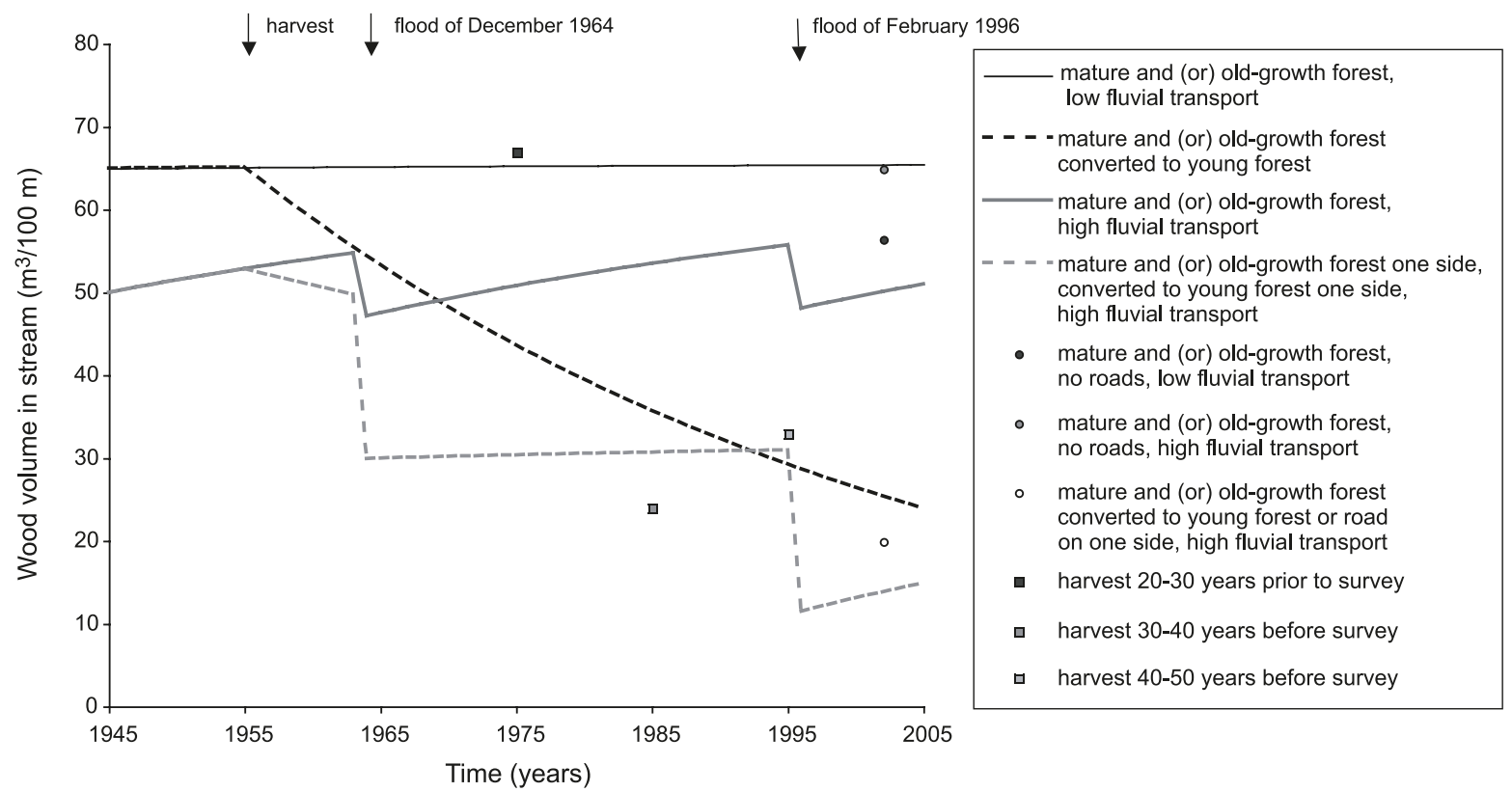

tributaries. Equally, the network-based approach fosters consideration of stream channels according to their ability to receive and retain wood from the entire upstream network, given likely geomorphic processes that deliver wood. For example, riparian buffers may be especially important along mainstem streams in wide, low-gradient valley floors that are unlikely to receive wood via debris flows from tributary channels and along mainstem channels where wood is frequently rearranged. A network dynamics perspective also may help in planning restoration of wood in streams by indicating suitable locations for conifer planting in riparian zones and wood placement in streams.

\section{Conclusions}

This study introduced a landscape-scale perspective of wood dynamics in streams that considers the interacting effects of forest patches, road networks, and stream networks on the sources and transport of wood in streams. Forest management practices from 50 years ago left discernible legacies in the form of depleted wood in certain portions of the study stream. Models such as those presented in this study could be used to simulate landscape dynamics over time and could be useful for predicting wood amounts. The network-patchwork perspective provides a basis for locating forest management activities in the landscape to sustain wood in forested stream networks.

\section{Acknowledgments}

This research was supported by National Science Foundation grants DEB-80-12162, BSR-85-14325, BSR-90-11663, DEB-96-32921, and DEB-02-18088 (H.J. Andrews Experi- mental Forest Long-Term Ecological Research (LTER)), by USDA Forest Service and US Geological Survey support of long-term monitoring at the H.J. Andrews Experimental Forest. Data and expertise were provided by J. Cissel, C. Creel, T. de Silva, G. Downing, D. Henshaw, A. Levno, G. Lienkaemper, J. Moreau, and S. Remillard. Two anonymous reviewers provided valuable input on the manuscript.

\section{References}

Benda, L.E., and Cundy, T.W. 1990. Predicting deposition of debris flows in mountain channels. Can. Geotech. J. 27: 409-417. doi:10.1139/t90-057.

Benda, L.E., and Sias, J.C. 1998. Landscape controls on wood abundance in streams. Study publication. Earth Systems Institute, Seattle, Wash.

Benda, L.E., Bigelow, P., and Worsley, T.M. 2002. Recruitment of wood to streams in old-growth and second-growth redwood forests, northern California, U.S.A. Can. J. For. Res. 32: 14601477. doi:10.1139/x02-065.

Benda, L., Andras, K., Miller, D., and Bigelow, P. 2004a. Confluence effects in rivers: interactions of basin scale, network geometry, and disturbance regimes. Water Resour. Res. 40: W05402. doi:10.1029/2003WR002583.

Benda, L.N., Poff, L., Miller, D., Dunne, T., Reeves, G., Pess, G., and Pollock, M. 2004b. The network dynamics hypothesis: how channel networks structure riverine habitats. Bioscience, 54: 413-427. doi:10.1641/0006-3568(2004)054[0413:TNDHHC]2.0. $\mathrm{CO} ; 2$.

Bigelow, P.E., Benda, L.E., Miller, D.J., and Burnett, K.M. 2007. On debris flows, river networks, and the spatial structure of channel morphology. For. Sci. 53: 220-238.

Bilby, R.E., and Ward, J.W. 1989. Changes in characteristics and function of woody debris with increasing size of streams in 
Western Washington. Trans. Am. Fish. Soc. 118: 368-378. doi:10.1577/1548-8659(1989)118<0368:CICAFO>2.3.CO;2.

Braudrick, C.A., Grant, G.E., Ishikawa, Y., and Ikeda, H. 1997. Dynamics of wood transport in streams: a flume experiment. Earth Surf. Processes Landforms, 22: 669-683. doi:10.1002/ (SICI)1096-9837(199707)22:7<669::AID-ESP740>3.0.CO;2-L.

Czarnomski, N.M. 2003. Effects of harvest and roads on in-stream wood abundance in the Blue River Basin, Western Cascades, Oregon. M.Sc. thesis. Oregon State University, Corvallis, Ore.

Dale, V.H., Swanson, F.J., and Crisafulli, C.M. 2005. Ecological responses to the 1980 eruption of Mount St. Helens. SpringerVerlag, New York.

Dreher, D.M. 2004. Effects of input and redistribution processes on in-stream wood abundance and arrangement in Lookout Creek, western Cascade Range, Oregon. M.Sc. thesis. Oregon State University, Corvallis, Ore.

Dyrness, C.T. 1967. Mass soil movements in the H.J. Andrews Experimental Forest. Res. Pap. PNW-42. USDA For. Serv. Pacific Northwest Forest and Range Experiment Station, Portland, Ore.

Faustini, J.M. 2000. Stream channel response to peak flows in a fifth-order mountain watershed. Ph.D. dissertation. Oregon State University, Corvallis, Ore.

Franklin, J.F., and Forman, R.T.T. 1987. Creating landscape patterns by forest cutting: ecological consequences and principles. Landsc. Ecol. 1: 5-18. doi:10.1007/BF02275261.

Forman, R.T.T., Sperling, D., Bissonette, J.A., Clevenger, A.P., Cutshall, C.D., Dale, V.H., Fahrig, L. et al. 2003. Road ecology: science and solutions. Island Press, Washington, D.C.

Gomi, T., Johnson, A.C., Deal, R.L., Hennon, P.E., Orlikowska, E.H., and Wipfli, M.S. 2006. Factors affecting distribution of wood, detritus, and sediment in headwater streams draining managed young-growth red alder - conifer forests in southeast Alaska. Can. J. For. Res. 36: 725-737. doi:10.1139/x05-272.

Grant, G.E., and Swanson, F.J. 1995. Morphology and processes of valley floors in mountain streams, western Cascades, Oregon. In Natural and anthropogenic influences in fluvial geomorphology. Edited by J.E. Costa, A.J. Miller, K.W. Potter, and P.R. Wilcock. Geophysical Monograph 89, American Geophysical Union. pp. 83-101.

Gregory, S.V., Boyer, K.L., and Gurnell, A.M. 2003. The ecology and management of wood in world rivers. Am. Fish. Soc. Symp. 37.

Gurnell, A.M., Piégay, H., Swanson, F.J., and Gregory, S.V. 2002. Large wood and fluvial processes. Freshw. Biol. 47: 601-619. doi:10.1046/j.1365-2427.2002.00916.x.

Harmon, M.E., Franklin, J.F., Swanson, F.J., Sollins, P., Gregory, S.V., Lattin, J.D., Anderson, N.H., Cline, S.P., Aumen, N.G., Sedell, J.R., Lienkaemper, G.W., Cromack, K., Jr., and Cummins, K.W. 1986. Ecology of coarse woody debris in temperate ecosystems. Adv. Ecol. Res, 15: 133-302.

Hyatt, T.L., and Naiman, R.J. 2001. The residence time of large woody debris in the Queets River, Washington, USA. Ecol. Appl. 11: 191-202. doi:10.1890/1051-0761(2001) 011[0191:TRTOLW]2.0.CO;2.

Johnson, S.L., Swanson, F.J., Grant, G.E., and Wondzell, S.M. 2000. Riparian forest disturbances by a mountain flood - the influence of floated wood. Hydrol. Process. 14: 3031-3050. doi:10.1002/1099-1085(200011/12)14:16/17<3031::AIDHYP133>3.0.CO;2-6.

Jones, J.A., and Grant, G.E. 1996. Peak flow responses to clearcutting and roads in small and large basins, western Cascades, Oregon. Water Resour. Res. 32: 959-974. doi:10.1029/ 95WR03493.

Jones, J.A., Swanson, F.J., Wemple, B.C., and Snyder, K.U. 2000.
Effects of roads on hydrology, geomorphology, and disturbance patches in stream networks. Conserv. Biol. 14: 76-85. doi:10. 1046/j.1523-1739.2000.99083.x.

Keim, R.F., Skaugset, A.E., and Bateman, S. 2000. Dynamics of coarse woody debris placed in three Oregon streams. For. Sci. 46: $13-22$.

Keller, E.A., and Swanson, F.J. 1979. Effects of large organic material on channel form and fluvial processes. Earth Surf. Process. 4: 361-380. doi:10.1002/esp.3290040406.

Lancaster, S.T., and Hayes, S.K. 2001. Modeling sediment and wood storage and dynamics in small mountainous watersheds. In Geomorphic processes and riverine habitat. Edited by J.M. Dorava, D.R. Montgomery, B.B. Palcsak, and F.A. Fitzpatrick. Water and Science Application. American Geophysical Union, Washington, D.C. pp. 85-102.

Lienkaemper, G.W., and Swanson, F.J. 1987. Dynamics of large woody debris in streams in old-growth Douglas-fir forests. Can. J. For. Res. 17: 150-156. doi:10.1139/x87-027.

Longley, P.A., Goodchild, M.F., Maguire, D.J., and Rhind, D.W. 2001. Geographic information systems and science. John Wiley \& Sons, Chichester, UK.

Marcus, W.A., Marston, R.A., Colvard, C.R., Jr., and Gray, R.D. 2002. Mapping the spatial and temporal distributions of woody debris in streams of the Greater Yellowstone Ecosystem, USA. Geomorphology, 44: 323-335. doi:10.1016/S0169-555X(01) 00181-7.

May, C.L., and Gresswell, R.E. 2003. Large wood recruitment and redistribution in headwater streams in the southern Oregon Coast Range, U.S.A. Can. J. For. Res. 33: 1352-1362. doi:10. 1139/x03-023.

May, C.L., and Gresswell, R.E. 2004. Spatial and temporal patterns of debris-flow deposition in the Oregon Coast Range, USA. Geomorphology, 57: 135-149. doi:10.1016/S0169-555X(03) 00086-2.

McDade, M.H., Swanson, F.J., McKee, W.A., Franklin, J.F., and VanSickle, J. 1990. Source distances for coarse woody debris entering small streams in western Oregon and Washington. Can. J. For. Res. 20: 326-330. doi:10.1139/x90-047.

Meleason, M.A., Gregory, S.V., and Bolte, J.P. 2003. Implications of riparian management strategies on wood in streams of the Pacific Northwest. Ecol. Appl. 13: 1212-1221. doi:10.1890/ 02-5004.

Morrison, P.H., and Swanson, F.J. 1990. Fire history and pattern in a Cascade Range landscape. USDA For. Serv. Gen. Tech. Rep. PNW-GTR-254.

Nakamura, F., and Swanson, F.J. 1993. Effects of coarse woody debris on morphology and sediment storage of a mountain stream system in western Oregon. Earth Surf. Processes Landforms, 18: 43-61. doi:10.1002/esp.3290180104.

Nakamura, F., and Swanson, F.J. 1994. Distribution of coarse woody debris in a mountain stream, western Cascade Range, Oregon. Can. J. For. Res. 24: 2395-2403. doi:10.1139/x94-309.

Nakamura, F., Swanson, F.J., and Wondzell, S.M. 2000. Disturbance regimes of stream and riparian systems - a disturbancecascade perspective. Hydrol. Process. 14: 2849-2860. doi:10. 1002/1099-1085(200011/12)14:16/17<2849::AID-HYP123>3.0. $\mathrm{CO} ; 2-\mathrm{X}$.

Ramsay, F.L., and Schafer, D.W. 1997. The statistical sleuth: a course in methods of data analysis. Duxbury Press, London.

Reeves, G.H., Benda, L.E., Burnett, K.M., Bisson, P.A., and Sedell, J.R. 1995. A disturbance-based ecosystem approach to maintaining and restoring freshwater habitats of evolutionary significant units of anadromous salmonids in the Pacific Northwest. Am. Fish. Soc. Symp. 17: 334-349. 
Reeves, G.H., Burnett, K.M., and McGarry, E.V. 2003. Sources of large wood in the main stem of a fourth-order watershed in coastal Oregon. Can. J. For. Res. 33: 1363-1370. doi:10.1139/ x03-095.

Ripple, W.J., Bradshaw, G.A., and Spies, T.A. 1991. Measuring forest landscape patterns in the Cascade Range of Oregon, USA. Biol. Conserv. 57: 73-88. doi:10.1016/0006-3207(91) 90108-L.

Sidle, R.C., Pearce, A.J., and O'Loughlin, C.L. 1985. Hillslope stability and land use. Water Resources Monograph 11. American Geophysical Union, Washington, D.C.

Silen, R.R. 1955. More efficient road patterns for a Douglas Fir drainage. Timberman, 56: 82-88.

Skaugset, A., and Wemple, B.C. 1999. The response of forest roads on steep, landslide-prone terrain in western Oregon to the February 1996 storm. In Proceedings of the International Mountain Logging and 10th Pacific Northwest Skyline Symposium. Edited by J. Session and W. Chung. International Union of Forestry Research Organizations, Corvallis, Ore. pp. 193-203.

Smith, J.W. 2002. Mapping the thermal climate of the H.J. Andrews Experimental Forest, Oregon. M.Sc thesis. Oregon State University, Corvallis, Ore.

Snyder, K.U. 2000. Debris flows and flood disturbance in small, mountain watersheds. M.Sc. thesis. Oregon State University, Corvallis, Ore.

Swanson, F.J. 2003. Wood in rivers: a landscape perspective. In The ecology and management of wood in world rivers. Edited by S.V. Gregory, K.L. Boyer, and A.M. Gurnell. Am. Fish. Soc. Symp. 37: 299-313.

Swanson, F.J., and Dyrness, C.T. 1975. Impact of clear-cutting and road construction on soil erosion by landslides in the western Cascade Range, Oregon. Geology, 3: 393-396. doi:10.1130/ 0091-7613(1975)3<393:IOCARC > 2.0.CO;2.

Swanson, F.J., and James, M.E. 1975. Geology and geomorphology of the H.J. Andrews Experimental Forest, western Cascades, Oregon. USDA For. Serv. Res. Pap. PNW-188. Pacific Northwest Forest and Range Experiment Station, Portland, Ore.

Swanson, F.J., and Jones, J.A. 2002. Geomorphology and hydrol- ogy of the H.J. Andrews Experimental Forest, Blue River, Oregon. In Field guide to geologic processes in Cascadia. Edited by G.W. Moore. Oregon Department of Geology and Mineral Industries, Special Paper 36. Nature of the Northwest Information Center, Portland, Ore. pp. 288-314.

Swanson, F.J., Lienkaemper, G.W., and Sedell, J.R. 1976. History, physical effects, and management implications of large organic debris in western Oregon streams. USDA For. Serv. Pacific Northwest Forest and Range Experiment Station Gen. Tech. Rep. 56, Portland, Ore.

Swanson, F.J., Franklin, J.F., and Sedell, J.R. 1990. Landscape patterns, disturbance, and management in the Pacific Northwest, USA. In Changing landscapes: an ecological perspective. Edited by I.S. Zonneveld and R.T.T. Forman. Springer, New York. pp. 191-213.

Swanson, F.J., Johnson, S.L., Gregory, S.V., and Acker, S.A. 1998. Flood disturbance in a forested mountain landscape. Bioscience, 48: 681-689. doi:10.2307/1313331.

USDA Forest Service and USDI Bureau of Land Management. 1994. Record of decision for amendments to Forest Service and Bureau of Land Management planning documents within the range of the northern spotted owl. USDA For. Serv. Regional Office, Portland, Ore.

Wemple, B.C., Jones, J.A., and Grant, G.E. 1996. Channel network extension by logging roads in two basins, western Cascades, Oregon. Water Resour. Bull. 32: 1195-1207.

Wemple, B.C., Swanson, F.J., and Jones, J.A. 2001. Forest roads and geomorphic process interactions, Cascade Range, Oregon. Earth Surf. Processes Landforms, 26: 191-204. doi:10.1002/ 1096-9837(200102)26:2<191::AID-ESP175>3.0.CO;2-U.

Wondzell, S.M., and Swanson, F.J. 1999. Floods, channel change, and the hyporheic zone. Water Resour. Res. 35: 555-567. doi:10.1029/1998WR900047.

Zelt, R.B., and Wohl, E.E. 2004. Channel and woody debris characteristics in adjacent burned and unburned watersheds a decade after wildfire, Park County, Wyoming. Geomorphology, 57: 217-233. doi:10.1016/S0169-555X(03)00104-1. 